\title{
Fzd7 (Frizzled-7) Expressed by Endothelial Cells Controls Blood Vessel Formation Through Wnt/B-Catenin Canonical Signaling
}

\author{
Claire Peghaire, Marie Lise Bats, Raj Sewduth, Sylvie Jeanningros, Beatrice Jaspard, \\ Thierry Couffinhal, Cécile Duplàa, Pascale Dufourcq
}

Objective - Vessel formation requires precise orchestration of a series of morphometric and molecular events controlled by a multitude of angiogenic factors and morphogens. Wnt/frizzled signaling is required for proper vascular formation. In this study, we investigated the role of the Fzd7 (frizzled-7) receptor in retinal vascular development and its relationship with the Wnt/ $\beta$-catenin canonical pathway and Notch signaling.

Approach and Results - Using transgenic mice, we demonstrated that Fzd7 is required for postnatal vascular formation. Endothelial cell (EC) deletion of $f z d 7$ ( $f z d 7^{\mathrm{ECKO}}$ ) delayed retinal plexus formation because of an impairment in tip cell phenotype and a decrease in stalk cell proliferation. Dvl (dishevelled) proteins are a main component of Wnt signaling and play a functionally redundant role. We found that $D v l 3$ depletion in $d v l 1^{-/-}$mice mimicked the $f z d 7^{\text {ЕСКO }}$ vascular phenotype and demonstrated that Fzd7 acted via $\beta$-catenin activation by showing that $\mathrm{LiCl}$ treatment rescued impairment in tip and stalk cell phenotypes induced in $f z d 7$ mutants. Deletion of $f z d 7$ or $D v l l / 3$ induced a strong decrease in Wnt canonical genes and Notch partners' expression. Genetic and pharmacological rescue strategies demonstrated that Fzd7 acted via $\beta$-catenin activation, upstream of Notch signaling to control Dl14 and Jagged1 EC expression.

Conclusions-Fzd7 expressed by EC drives postnatal angiogenesis via activation of Dvl/ $\beta$-catenin signaling and can control the integrative interaction of Wnt and Notch signaling during postnatal angiogenesis. (Arterioscler Thromb Vasc Biol. 2016;36:2369-2380. DOI: 10.1161/ATVBAHA.116.307926.)

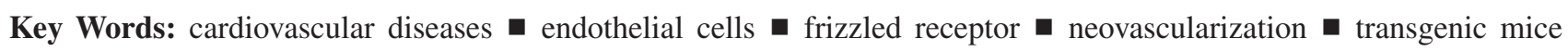

$\mathrm{U}$ nderstanding development and vessel formation in an organ is important in the context of developmental biology, oncology, regenerative medicine, and cardiovascular diseases. A majority of newly extended vessel networks are formed via angiogenesis, a process by which new blood vessels are generated from existing blood vessels. ${ }^{1}$ These complex dynamic steps need to be co-ordinated by different molecular pathways regulating migration, proliferation, and differentiation of endothelial cells (EC).

The Wnt/frizzled (Fzd) pathway, an important pathway in embryonic development, has recently been implicated in vessel formation and EC differentiation. ${ }^{2-4} \mathrm{Wnt} /$ Fzd signaling comprised a complex pathway with 19 soluble Wnt proteins that can bind to $10 \mathrm{Fzd}$ (Fzd1-10) receptors and activate canonical and noncanonical signaling pathways, so-called planar cell polarity, or the $\mathrm{Wnt} / \mathrm{Ca}^{2+}$ pathway. ${ }^{5,6}$ Induction of the Wnt canonical pathway begins with activation of Fzd receptors and LRP (low-density lipoprotein-related protein)
$5 / 6$ coreceptors and the recruitment of the scaffolding protein Dvl (dishevelled). Dvl acts by interacting with the $\beta$-catenin degradation complex, which leads to stabilization and accumulation of $\beta$-catenin in the cytosol, which can translocate into the nucleus. $\beta$-Catenin binds to the Lef-Tcf family of transcription factors to induce expression of target genes. ${ }^{7,8}$

Similar to Wnt signaling, Notch signaling is a highly conserved pathway and controls different processes of angiogenesis. ${ }^{9}$ An interplay between Wnt and Notch signaling has recently been elicited during vascular development and tumoral angiogenesis because the Wnt canonical pathway and Notch signaling regulate each other. ${ }^{10-12}$ However, the nature of Wnt/Notch cross talk in regulating EC fate is still not fully understood in postnatal angiogenesis, and the identification of the Fzd receptor upstream of this cross talk is still unknown.

Recently, we identified Fzd7 (frizzled-7) as a new receptor at the surface of EC controlling vascular permeability via the canonical Wnt/Fzd pathway. ${ }^{13}$ Fzd7 plays an important role in

Received on: May 31, 2016; final version accepted on: September 22, 2016.

From the Biology of Cardiovascular Diseases, INSERM U1034, Pessac, France (M.L.B., S.J., B.J., T.C., C.D., P.D.); Biology of Cardiovascular Diseases, University of Bordeaux, U1034, France (M.L.B., B.J., T.C., C.D., P.D.); Service des Maladies cardiaques et vasculaires (T.C.) and Service de Biochimie clinique (M.L.B.), CHU de Bordeaux, France; National Heart and Lung Institute, Vascular Science, Imperial Center for Translational and Experimental Medicine, Imperial College London, Hammersmith Hospital, United Kingdom (C.P.); and Laboratorium voor Endotheliale Moleculaire Biologie, Vesalius Research Center, Leuven, Belgium (R.S.).

The online-only Data Supplement is available with this article at http://atvb.ahajournals.org/lookup/suppl/doi:10.1161/ATVBAHA.116.307926/-/DC1.

Correspondence to Pascale Dufourcq, Biology of Cardiovascular Diseases, INSERM U1034, 1 Ave de Magellan, 33600 Pessac, France. E-mail pascale. dufourcq@u-bordeaux.fr

(C) 2016 American Heart Association, Inc.

Arterioscler Thromb Vasc Biol is available at http://atvb.ahajournals.org 


\begin{tabular}{|ll|}
\hline \multicolumn{2}{|l|}{ Nonstandard Abbreviations and Acronyms } \\
\hline Dvl & dishevelled \\
EC & endothelial cell \\
Fzd & frizzled \\
LRP & low-density lipoprotein-related protein \\
P & postnatal day \\
\hline
\end{tabular}

development, ${ }^{14,15}$ as well as in stem cell renewal and differentiation. ${ }^{16-18}$ Fzd7 is the most commonly upregulated Wnt receptor in a variety of cancers, has been shown to promote cancer development and progression, and has emerged as a target for cancer therapy. ${ }^{19,20}$ In this study, we investigated the role of the Fzd7 receptor in retinal vascular development. We reported that EC deletion of $f z d 7$ delays retinal plexus formation with an impairment in tip cell phenotype and a decrease in stalk cell proliferation. Retinal knockdown of $d v l 3$, in null mutant mice deficient in $d v l l$, mimicked the defects induced by $f z d 7$ deletion. Pharmacological and genetic rescue strategies demonstrated that Fzd7 controls angiogenesis and contributes to retinal vascular development through the Wnt canonical pathway, acting upstream of Notch signaling via the regulation of Jagged1 and D114 expression.

\section{Materials and Methods}

Materials and Methods are available in the online-only Data Supplement.

\section{Results \\ Fzd7 Is Expressed in EC During Retinal Vascular Formation}

Using a model of postnatal retinal angiogenesis, we investigated the expression of Fzd7 during blood vessel formation. Analysis of total retinal extract by quantitative polymerase chain reaction ( $\mathrm{qPCR}$ ) showed an increase in $f z d 7$ expression from postnatal day (P) 5 to $\mathrm{P} 15$ before returning to baseline levels at P21 (Figure 1A). Temporally, this increase occurred during the period of primary (P5-P7) and deep (P15) vascular plexus formation. To analyze the localization of Fzd7, confocal analysis of $\mathrm{P} 7$ retinal sections, stained with CD31 and Fzd7, was performed (Figure 1B and 1C). Fzd7 was observed in $\mathrm{CD}_{31} 1^{+}$cells in the primary vascular plexus while its expression was not restricted to EC (Figure 1B and 1C).

\section{EC Deletion of $f z d 7$ Delays Retinal Vascular Formation}

To investigate the specific role of $f z d 7$ in EC during retinal vascular development, we generated different transgenic mice: $f z d 7^{E C K O}$ with constitutive (Tie2-Cre) and $f z d 7^{\text {ЕСКО }}$ with inducible (Pdgfb-iCre) EC deletion (Figure IA in the online-only Data Supplement). In $f z d 7^{i E C K O}$ mice, we induced recombination by tamoxifen injection at the P1, P2, and P3 postnatal stages. The efficiency of Cre expression in the retina was verified using $\mathrm{mT} /$ $\mathrm{mG}$ reporter mice for both lines (Figure IB and IC in the onlineonly Data Supplement). qPCR of whole retinal extracts showed a reduction of $f z d 7$ expression in $f z d 7^{E C K O}$ and $f z d 7^{i E C K O}$ mice, as compared with their respective controls (Figure ID and IE in the online-only Data Supplement). Specific deletion was demonstrated by a decrease of Fzd7 mRNA in CD31+ EC isolated from lung (Figure IF in the online-only Data Supplement) and the absence of EC-specific Fzd7 staining in the mutant retina (Figure IG in the online-only Data Supplement). It is worth noting that both $f z d 7^{E C K O}$ and tamoxifen-treated $f z d 7^{\text {IECKO }}$ mice did not differ in weight when compared with their respective controls (Figure IH in the online-only Data Supplement).

The retina is avascular at birth, and outgrowth of the first vascular plexus, the superficial retinal vascular plexus, progresses from the center to the periphery from P1 until P8. Retina from both mutant mice had delayed vascularization in the superficial retinal vascular plexus at P5 and P7, with a reduction in the extent of vascular coverage and radial expansion from the optic nerve to the periphery (Figure $2 \mathrm{~A}$ through $2 \mathrm{C}$ ). Because $f z d 7$ was strongly induced in the retina at $\mathrm{P} 15$, we next investigated whether secondary and tertiary layers of the retinal vasculature could be formed in $f z d 7$ mutant mice. Interestingly, at P11, the deep capillary plexus was significantly reduced in retina from $f z d 7^{E C K O}$ and $f z d 7^{i E C K O}$ mice (Figure 2D), demonstrating that Fzd7 is required for the formation of different vascular plexus. It has been previously proposed that $\mathrm{Fzd} 7$ is expressed in myeloid cells. ${ }^{21}$ To exclude a possible contribution of these cells to the vascular phenotype in $f z d 7^{\mathrm{F} / \mathrm{F}}$; Tie2-Cre mice, we conditionally deleted $f z d 7$ in myeloid cells using the M lysozyme-Cre line (LysM-Cre). $f z d 7$-LysM-Cre(+) mice developed a retinal vascular plexus similar to control mice, indicating that myeloid Fzd7 is not required for retinal vascularization (Figure II in the online-only Data Supplement). Collectively, these results support the hypothesis that EC-dependent Fzd7 signaling is critical for retinal vascular development.

\section{$f z d 7$ Deletion in EC Impaired Tip Cell Phenotype and Stalk Cell Proliferation}

To better understand vascular formation and remodeling changes associated with an EC-specific $f z d 7$ deletion, we quantified morphometric and angiogenic parameters in $f z d 7^{i E C K O}$ mice (Figure 3). Remarkably, at the vascular front, a significant increase in tip cell numbers was observed in $f z d 7$-deficient vessels at P7 (Figure 3A). Filopodia mediate endothelial tip cell migration to guide vascular sprout formation and anastomosis. ${ }^{22,23}$ High-resolution analysis of tip cells identified an increase in filopodia protrusions. Moreover, the majority of filopodia (80\%) showed an angle profile between 0 and $45^{\circ}$ in controls, whereas in retina from $f z d 7^{i E C K O}$ mice, filopodia were randomly positioned with a wider angle profile (Figure 3A). Finally, the number of branch points was quantified in different zones across the vascular plexus and revealed a significant increase in vascular density in the venous region of retina from $f_{z} d 7^{i E C K O}$ mice but no significant modification in the arterial zone (Figure 3D). All these data suggest that tip cell function and the process of vessel sprouting is impaired in $f z d 7^{i E C K O}$ mice.

EC proliferation at P7 is observed in stalk cells at the leading edge of growing plexus, in veins and to a lesser extent in arteries. ${ }^{24}$ We found significantly reduced proliferation rates of isolectin $\mathrm{B}^{+} \mathrm{ECs}$ in $f z d 7^{\mathrm{E} C \text { EKO }}$ retina at $\mathrm{P} 7$ (Figure $3 \mathrm{~B}$ ) in the stalk cell area, whereas no modification in proliferation was observed in the vein or artery (data not shown). In contrast, 


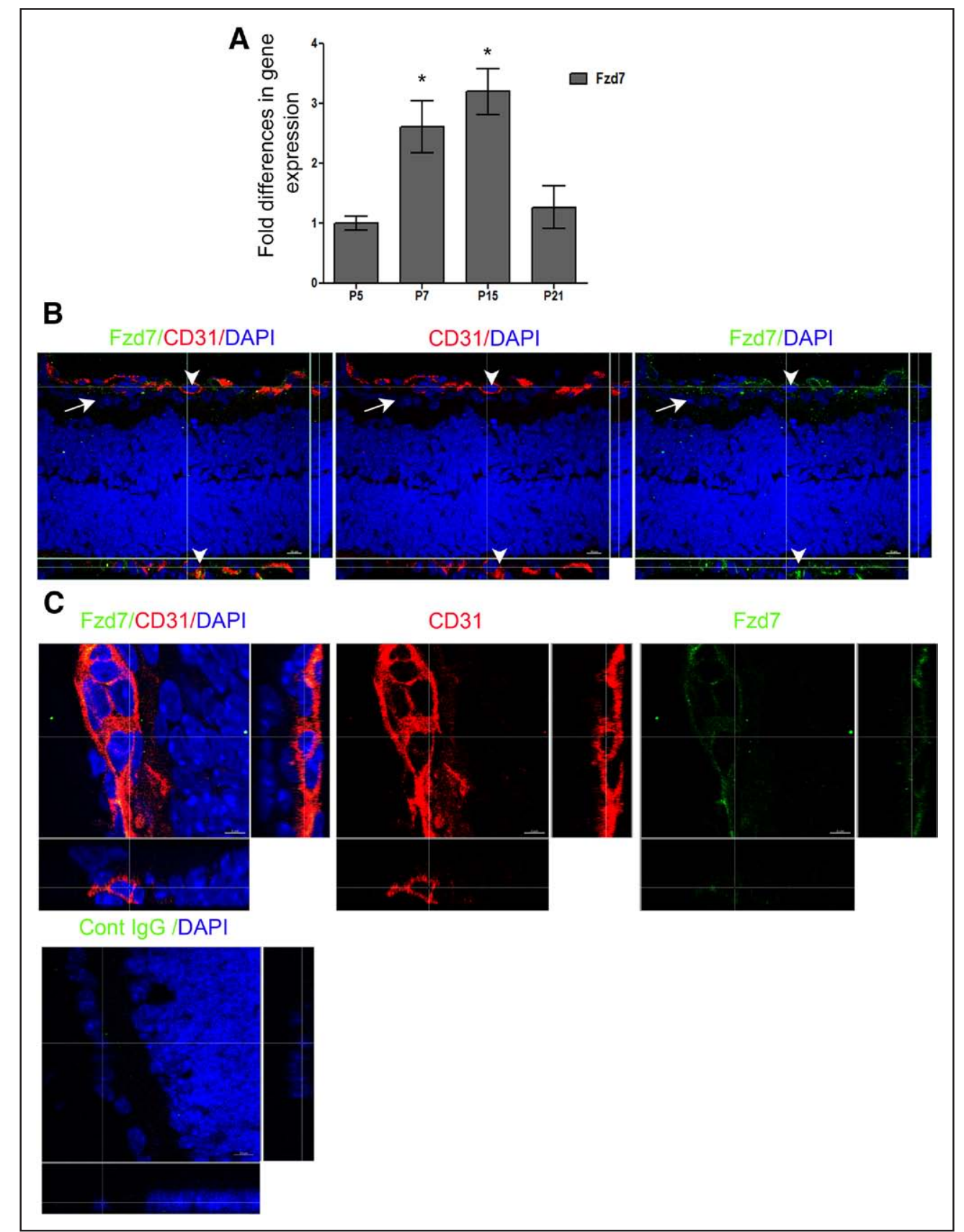

Figure 1. Fzd7 (frizzled-7) is expressed during postnatal angiogenesis in mouse retina. A, Quantification of fzd7 mRNA was performed during retinal vascular development by qRT-PCR of retina at postnatal day (P) 5 to P21. Expression level of $f z d 7$ was normalized against the housekeeping gene $\beta$-actin. Data represent the mean of 4 experiments performed in triplicate. ${ }^{\star} P<0.005$. B and $\mathbf{C}$, Confocal images of P7 frozen sections stained with CD31 antibody for vessels (red), Fzd7 (green), or control lgG (green) and DAPI for nuclei (blue). In the primary vascular plexus of the retina, endothelial cell (EC) expressed Fzd7 (white arrowhead). B, High magnification of retinal vessel (C). White arrow head: Fzd7 ${ }^{+} / \mathrm{CD} 31^{+}$; white arrow: Fzd7 ${ }^{+} / \mathrm{CD} 31^{-}$. Scale bar=10 or $5 \mu \mathrm{m}$.

vascular remodeling across the plexus was analyzed using retinas stained with collagen IV and isolectin B4 and did not reveal significant impairment in vessel regression in $f z d 7$-deficient vessels (Figure 3C).

\section{Silencing $d v l 3$ in $d v l 1^{-/-}$Mice Mimicked the Defects Induced by $f z d 7$ Deletion}

Our group has previously demonstrated that Fzd7 can recruit Dv11 and 3 at the cell membrane to activate EC signaling ${ }^{25}$; therefore, we sought to compare retina from $d v l 1^{-/-}$mice with those from $f z d 7^{\text {ECKO }}$ mice. We observed a significant delay and incomplete outgrowth of the superficial retinal vascular plexus with reduced vascular area (Figure 4A) and radial expansion at P5 (Figure 4B) and P7 (Figure 4C). Moreover, increased tip cell number at the leading edge at P5 and P7 was observed in $d v l 1^{-/-}$mice (Figure 4B and $4 \mathrm{C}$ ). There was no modification in body weight between $d v l 1^{-/-}$and $d v l 1^{+/+}$mice (Figure IIIA in the online-only Data Supplement). Because $d v l 1^{-/-}$retinal phenotype was similar but less severe than that of $f z d 7^{i E C K O}$ mice, we then asked whether this mild effect might be linked to a 


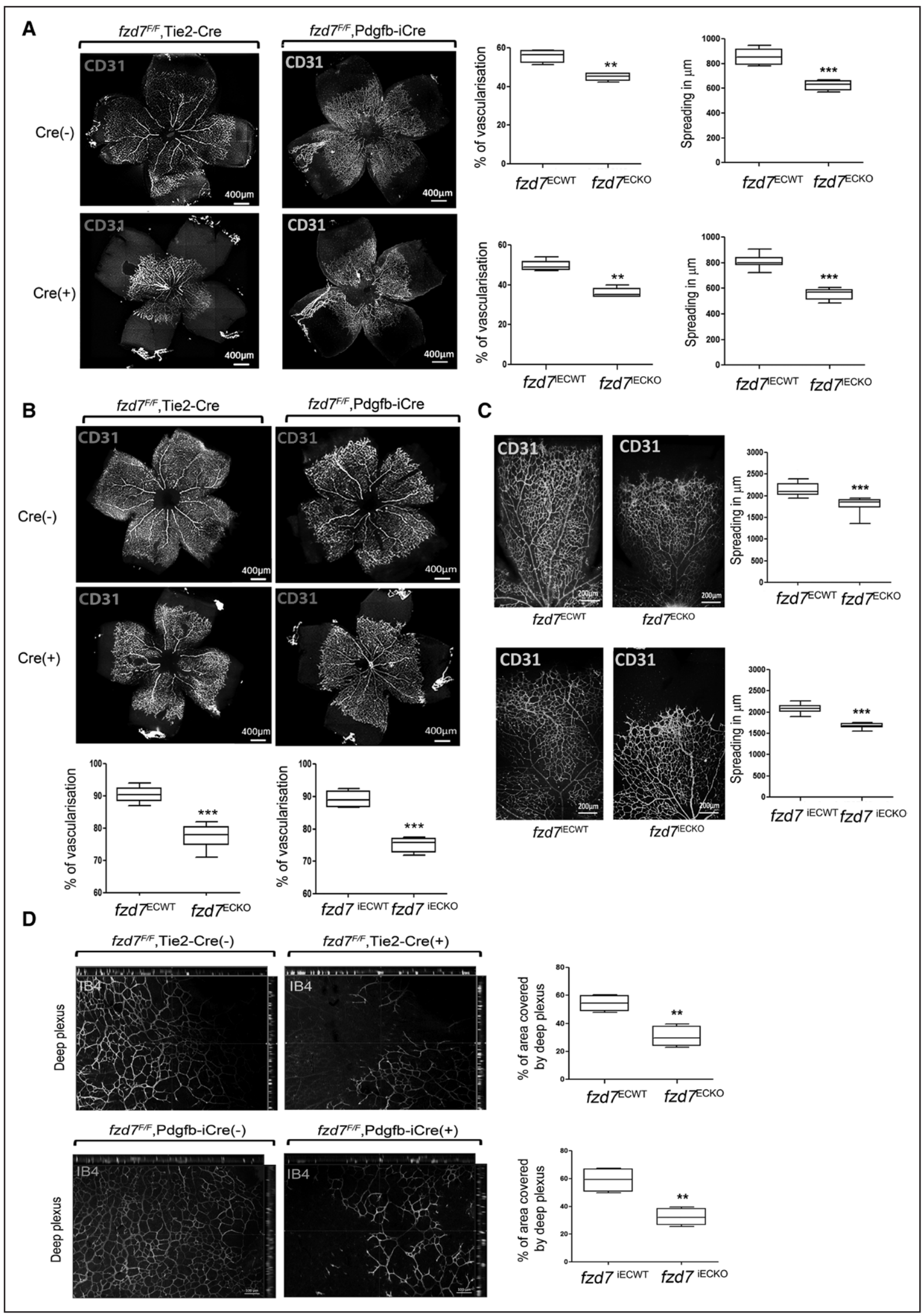

Figure 2. Effects of conditional endothelial cell (EC) deletion of $f z d 7$ during retinal vascular formation. A-D, Representative whole mount retina from $f z d 7^{F / F}$,Tie2-Cre(-) or $\mathrm{Cre}(+)$ and $f z d 7^{F / F}, \mathrm{Pdgfb}-\mathrm{iCre}(-)$ or $\mathrm{Cre}(+)$ mice stained with CD31 to visualize vessels at postnatal day (P) 5 (A), P7 (B-C), and P11 (D). Quantification of the percentage of vascularization and spreading showed a strong delay in vascular formation in $f z d 7$ mutant mice. Scale bar $=400$ or $200 \mu \mathrm{m}$. $\mathrm{n}=10$ for each genotype. ${ }^{\star \star} P<0.005 ;{ }^{\star \star \star} P<0.0001$. 


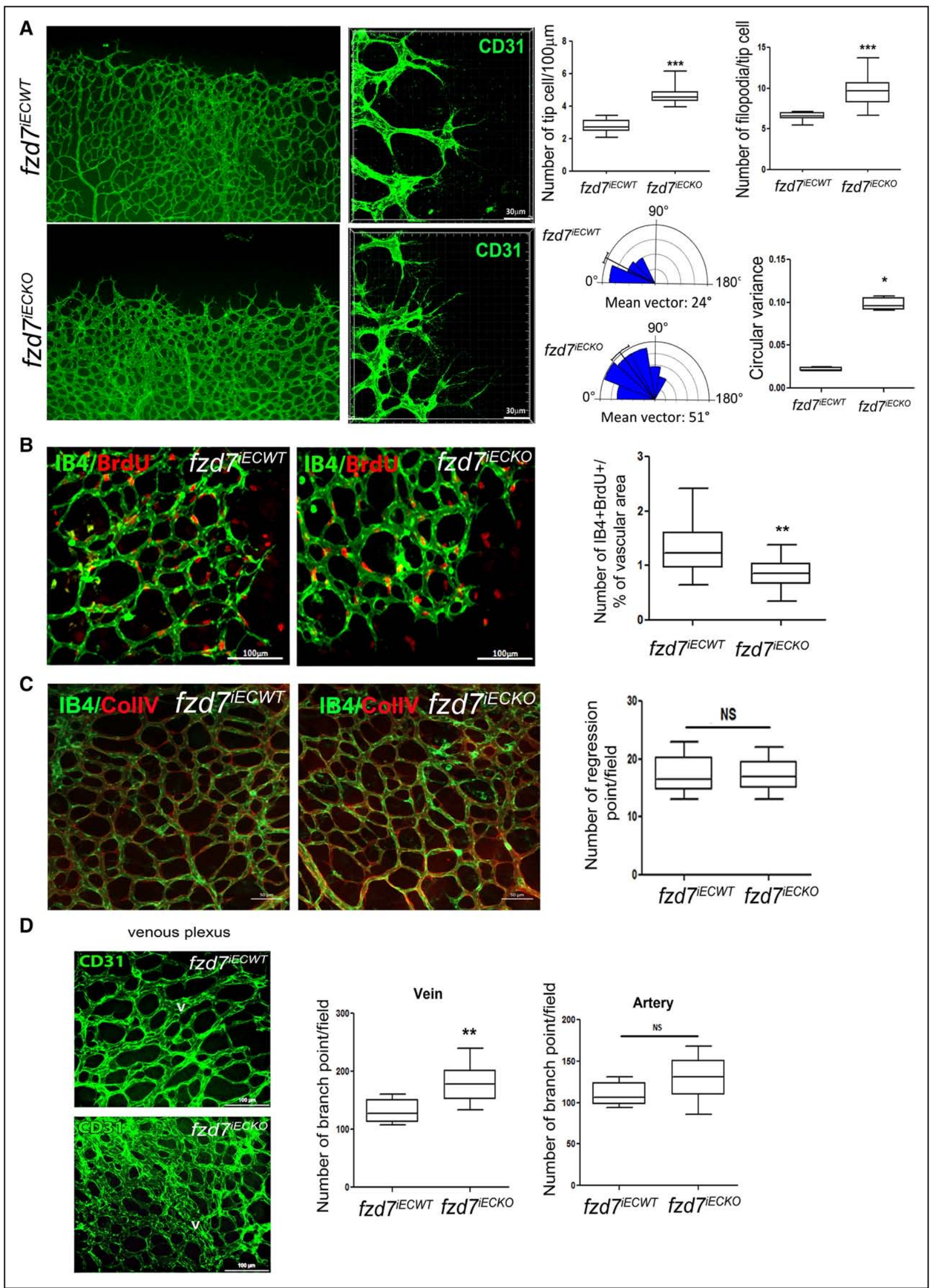

Figure 3. Fzd7 (frizzled-7) deletion impaired tip cell phenotype and stalk cell proliferation. A, Retinal whole mounts of $f z d 7^{i E C W T}$ and $f z d 7^{i E C K O}$ mice stained with isolectin B4 (IB4) or CD31 antibody at postnatal day (P) 7. Number of tip cells per $100 \mu \mathrm{m}$ quantified after IB4 staining at P7 was increased in $f z d 7$ mutants: $f z d 7^{i E C W T}(n=8)$ vs $f z d 7^{i E C K O}(n=10)$. Scale bar=100 $\mu$ m. High magnification of tip cell $(C o n t i n u e d)$ 
Figure 3 Continued. filopodia was analyzed after confocal analysis of CD31 staining. Quantification of filopodia showed a strong increase in the number of filopodia per tip cell in $f z d 7$ deleted mice ( $n=6$ mice). For each filopodia, measurement of the angle between the filopodia and the tip cell axis was performed. A representative distribution of filopodia in one fzd7iECWT and one $f z d 7^{i E C K O}$ retina is represented (mean vector represents mean angle of filopodia). Circular variance indicates how much each orientation deviates from the mean ( $n=5$ mice). Scale=30 $\mu \mathrm{m}$. B, Quantification of BrdU- (bromo-desoxy-uridin; red) and IB4- (green) positive nuclei on the vascular surface illustrates the decrease in endothelial cell (EC) proliferation at P7: $n=6$ mice; scale bar $=100 \mu \mathrm{m}$. C, Vessel regression was evaluated after IB4 and collagen IV staining; the number of IB4-/Coll IV+ points per field was not altered: $f z d 7^{i E C W T}(\mathrm{n}=5)$ and $f z d 7^{i E C K O}(\mathrm{n}=6)$. D, The number of branch points per field after CD31 staining was quantified at P7 in the venous and arterial zones: $n=6$ mice; scale bar $=100 \mu \mathrm{m}$. Fzd7 deletion increased the number of branches in the venous zone, whereas no significant modification was observed around the arteries. $V$ indicates vein. ${ }^{*} P<0.05 ;{ }^{* \star} P<0.005$; ${ }^{\star \star \star} P<0.0001$.

compensatory redundant Dvl isoform function. We analyzed expression rates of $d v l$ isoforms in $d v l 1^{-/-}$retina and found a significant increase in $d v l 3$ without modification of $d v l 2$ transcripts (Fig IIIB in the online-only Data Supplement), suggesting that Dvl1 and Dvl3 could have redundant functions. To test this, we investigated the vascular phenotype of $d v l 1^{-/-}$ mice injected with siRNA targeting $d v l 3$ or control siRNA in the contralateral eye of the same animal. In control mice, we found that sidvl3 injection efficiently reduced the level of $d v l 3$ mRNA $(\approx 60 \%)$, whereas no modification in $d v l l$ or $d v l 2$ was observed (Figure IIIC in the online-only Data Supplement). In $\mathrm{dv} l 1^{+/+}$littermates, loss of $d v l 3$ did not modify the vascular area; however, it did significantly increase the number of tip cells (Figure 4C). When $d v l 3$ was silenced in $d v l 1^{-/-}$mice, double deletion significantly delayed the vascular outgrowth and enhanced the increase in tip cell number (Figure 4C). These data demonstrate that $d v l 1 / 3$ deletion mimicked the vascular phenotype induced by $f z d 7$ deletion.

\section{Fzd7 Deletion Decreases Wnt Canonical Target Genes and Notch Partner Expression}

We next analyzed whether Fzd7/Dvl could control vascular development via Wnt canonical signaling, as previously reported in cultured EC. ${ }^{13}$ Quantitative analysis by Western blot showed a decrease of the activated form of $\beta$-catenin in lysate from $f z d 7^{\mathrm{iECKO}}$ retina (Figure $5 \mathrm{~A}$ ) and by RT-qPCR a downregulation of Axin2 and Lef1 genes, 2 main Wnt canonical target genes (Figure 5B). Interestingly, we obtained a similar effect in $d v l 1^{-1-}$ retina extracts on Axin2 and Lefl gene expression (Figure 5C).

Because the Fzd4/LRP5/Norrin pathway has been reported to regulate postnatal angiogenesis via the $\beta$-catenin pathway, ${ }^{26-29}$ we investigated mRNA expression of $f z d 4, L R P 5$, and Norrin in total retina. No modification of these transcripts was observed in tissue from $f z d 7^{\mathrm{iECKO}}$ versus $f z d 7^{\mathrm{ECWT}}$ mice (Figure 5D), suggesting that the vascular defect in $f z d 7$ mutant is not because of Fzd4/LRP5/Norrin signaling impairment.

The Notch pathway is crucial for vascular development in postnatal retina and has been shown to be regulated by $\beta$-catenin transactivation activity in embryonic EC, during tumoral angiogenesis or in non-EC. ${ }^{10,12,30} \mathrm{We}$, therefore, hypothesized that $f z d 7$ deletion may impair Notch signaling. qPCR performed on retina extracts consistently demonstrated that EC deletion of $f z d 7$ strongly decreased Notch pathway gene expression (Figure 6A). Expression of Notch ligands, Dll4 and Jagl, were downregulated by $>80 \%$, whereas Notch1 and 4, Heyl, and Nrarp transcripts were downregulated by $60 \%$ to $70 \%$ in $f z d 7^{i E C K O}$ retina (Figure $6 \mathrm{~A}$ ). Impairment in Notch gene expression was confirmed in EC isolated from $f z d 7^{\text {iECKO }}$ or $f z d 7^{i E C W T}$ mouse lung (Figure 6B). Moreover, in $f z d 7$-deficient retinal vasculature, we found that EC had significantly lower levels of D114 and Jagged1 protein in tip and stalk cells, respectively, as compared with their control littermate (Figure IVA and IVB in the online-only Data Supplement). Because loss of expression of EphrinB2 and an increase EphB4 were also observed in mice with targeted deletion of Notch signaling partners, ${ }^{31}$ we next investigated whether Fzd7 signaling could alter the EphrinB2/EphB4 balance. We found a significant decrease in the arterial marker Ephrin-B2 and an increase in the venous marker EphB4 expression at the mRNA (Figure 6C) and protein level (Figure 6D) in $f z d 7^{i E C K O}$ mouse retina.

We found that $d v l l$ deletion mirrored the effects of $f z d 7$ deletion on some Notch pathway genes, decreasing Dll4 and Hey2 transcript expression in $d v l 1^{-/-}$extracts (Figure 6E). Because deletion of $D v l l$ was not specific to EC, the direct effect of $d v l$ depletion on gene expression was next examined in cultured EC treated with different siRNA. Depletion of $d v l l$ or $d v l 3$ induced a significant decrease in Dll4, Notch1, and Hey2 mRNA expression in cultured EC, whereas $d v l 2$ siRNA had no effect (Figure 6F). We noted that this mild impact on Notch genes may be associated with the intermediate phenotype observed in $d v l 1^{-/-}$retina. Cotreatment of EC by $d v l l$ and $d v l 3$ siRNA had a synergic effect for Dll4 and Hey2 expression (Figure 6F). These results, taken together, suggest that Fzd7 might control angiogenesis by $\beta$-catenin signaling acting upstream of Notch signaling.

\section{Fzd7 Controls Blood Vessel Formation via the Wnt-Canonical Pathway}

$f z d 7^{i E C W T}$ and $f z d 7^{i E C K O}$ mice were treated with $\mathrm{LiCl}$, to determine whether this treatment rescued the $f z d 7$ deletion-induced retinal phenotype. Activation of the Wnt-signaling canonical pathway by $\mathrm{LiCl}$ treatment was confirmed by quantification of Lefl gene expression in control and $f z d 7$ mutant retina (Figure $7 \mathrm{~B}$ ). $\mathrm{LiCl}$ treatment in $f z d 7^{i E C W T}$ littermates did not modify tip cell number or vascular plexus spreading while EC proliferation was slightly increased (Figure 7A). In $f z d 7^{i E C K O}$ mice, $\mathrm{LiCl}$ treatment rescued the vascular outgrowth, impairment of tip and filopodia number, and stalk cell proliferation (Figure 7A). These results demonstrated that activation of the Wnt-canonical pathway completely rescued the $f z d 7^{i E C K O}$-induced phenotype and suggests that Fzd7 activates canonical Wnt signaling via Dvl1/3 to control retinal vascular development.

\section{Fzd7/ß-Catenin Signaling Controls the Notch Pathway During Postnatal Angiogenesis}

Next, we investigated whether Fzd7 regulates Notch signaling via the Wnt canonical pathway. qPCR of retina extracts showed that GSK3 $\beta$ inhibition by $\mathrm{LiCl}$ treatment activated the Notch pathway in $f z d 7^{i E C W T}$ mice as demonstrated by an increase in Dll4, Jag1, and Notch1 receptors Hey2 and Nrarp 


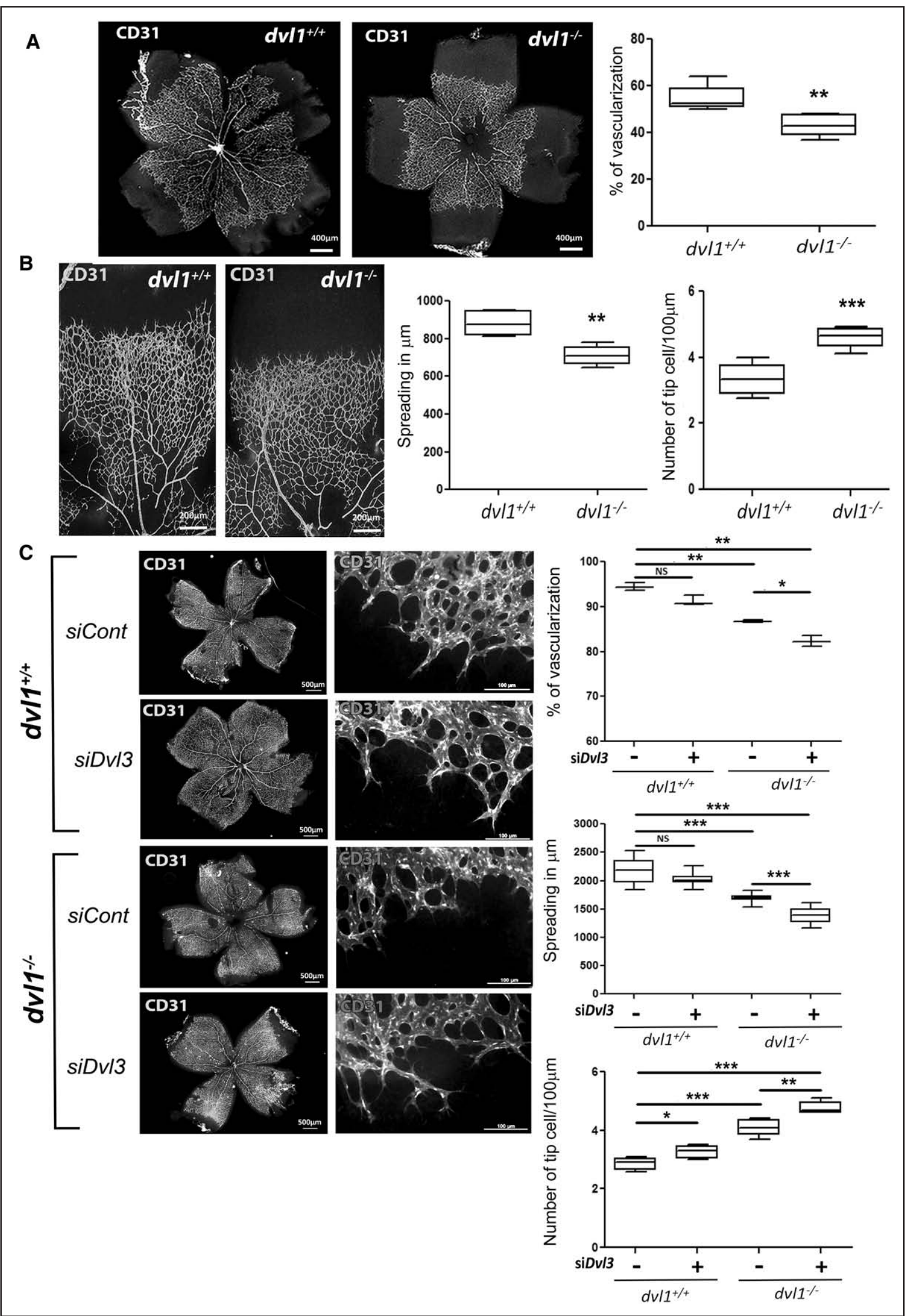

Figure 4. Deletion of $d v / 1$ (dishevelled-1) and knockdown of $d v / 3$ expression mimics the $f z d 7^{i E C K O}$ phenotype. A and B, Representative retinal whole mount or peripheral retinal flat mounts from $d v / 1^{+/+}$and $d v / 1^{-/-}$mice stained with CD31 antibody at postnatal day (P) 5 . Quantification of the \% vascularization (A) and vascular spreading (B) showed a significant delay in vascular plexus formation (Continued) 
Figure 4 Continued. in $d v / 1^{-/-}$mice and an increase in the number of tip cells per $100 \mu \mathrm{m}: \mathrm{n}=6$ mice. C, Representative retinal whole mount or peripheral retinal flat mount stained with CD31 antibody, from siCtl- or sidv/3-injected $d v / 1^{+/+}$and $d v / 1^{-/-}$mice at P7. The \% vascularization ( $n=3$ mice for each condition), vascular spreading, and the number of tip cells per $100 \mu$ m were quantified ( $n=5$ mice for each condition). Red stars indicate tip cells. ${ }^{\star} P<0.05 ;{ }^{* \star} P<0.005 ;{ }^{* \star \star} P<0.0001$.

mRNA expression (Figure 7C). Similarly, LiCl treatment rescued Notch pathway component expression in $f z d 7^{i E C K O}$ mice retina to a similar level (Figure 7C). Because $\mathrm{LiCl}$ could lead to indirect effects on other cells in the retina, in vitro experiments were performed using an siRNA strategy on MS1 cells. ${ }^{13}$ In cultured EC (MS1), $f z d 7$ silencing decreased expression of Dll4, Jag1, Notch 1, Hey2, and Nrarp. LiCl treatment prevented Notch pathway impairment under siRNA $f z d 7$ conditions (Figure 7D). As expected, when ECs were infected with lentivirus encoding for active $\beta$-catenin, active $\beta$-catenin strongly induced mRNA expression of Axin2, a downstream target of $\beta$-catenin, and Dll4, Jag1, and Hey2 Notch partners, in control EC (Figure 7D). Interestingly, in cultured $f z d 7$ knockdown ECs, downregulation of these genes was rescued by activated $\beta$-catenin (Figure 7D). These results demonstrate that Fzd7, via $\beta$-catenin transcriptional activity, controls the expression of both Dll4 and Jagl in addition to downstream Notch targets.

We next explored the potential rescue of the $f z d 7$ phenotype by Dll4 or Jagged1 activation in vitro because Dll4 and Jag1 signaling enhanced EphrinB2 and EC proliferation, respectively. ${ }^{31,32}$ In accordance with our in vivo results, $f z d 7$ knockdown significantly decreased EC proliferation in vitro (Figure 7E). Stimulation with immobilized Jag1 protein induced, as expected, a significant increase in EC proliferation. Interestingly, after Jagged 1 activation, the decrease in EC proliferation became less potent after $f z d 7$ knockdown, suggesting that Fzd7 may control proliferation partially via Jag1 signaling (Figure 7E). We next investigated whether Dll4 signaling could rescue the decrease of EphrinB2 expression induced by $f z d 7$ depletion (Figure 7F). Under Dll4 activation, EphrinB2 expression was totally rescued in cells depleted of $f z d 7$, suggesting that Fzd7/ $\beta$-catenin can control EphrinB2 expression via Dll4.

\section{Discussion}

We provide evidence that Fzd7 expressed by EC drives angiogenesis via the Wnt canonical pathway and contributes to retinal vascular development. We further demonstrate that Fzd7 signaling occurs predominantly via activation of $\mathrm{Dvl} / \beta$-catenin canonical Wnt signaling acting upstream of Notch signaling.

Using both constitutive and the inducible EC-specific deletion approaches, we show that $f z d 7$ deficiency results in a delay of primary retinal vascular plexus outgrowth, impairment in the tip cell phenotype, decreased stalk cell proliferation, and induced hyperbranching morphology in venous areas. Moreover, deletion of $f_{z} d 7$ in EC impaired deep plexus formation with a decrease in the vascular area of the tertiary plexus. In cell culture, ECs have been shown to express almost all of the Fzd receptors, and they have been shown to regulate EC survival, proliferation, and gene expression. ${ }^{2,4}$ In vivo, only 3 Fzd receptors have been demonstrated to be involved in angiogenesis by genetic deletion or soluble receptor strategies. Fzd5 is essential for yolk sac and placental angiogenesis. ${ }^{33}$ In the retina, Fzd5 has been implicated in eye formation and hyaloid vasculature regression. ${ }^{34} \mathrm{~A}$ soluble Fzd- 8 ectodomain, used to bind extracellular Wnt ligands, leads to severe central nervous system-specific angiogenesis defects. ${ }^{35}$ Global or EC-specific $f z d 4^{-/-}$mutants present a strong inhibition of different vascular plexus formation and hyaloid regression during postnatal angiogenesis. ${ }^{26,36,37}$ Our data provide a novel insight into the biology of Wnt/Fzd signaling during blood vessel morphogenesis and provide evidence of EC-autonomous effects of Fzd7 to control postnatal angiogenic processes.

Depending on the context, Fzd7 can activate either the Wntcanonical $\beta$-catenin pathway or the noncanonical Wnt pathway via Dvls. ${ }^{19,20}$ Dvls are considered to be a central hub for Wnt/

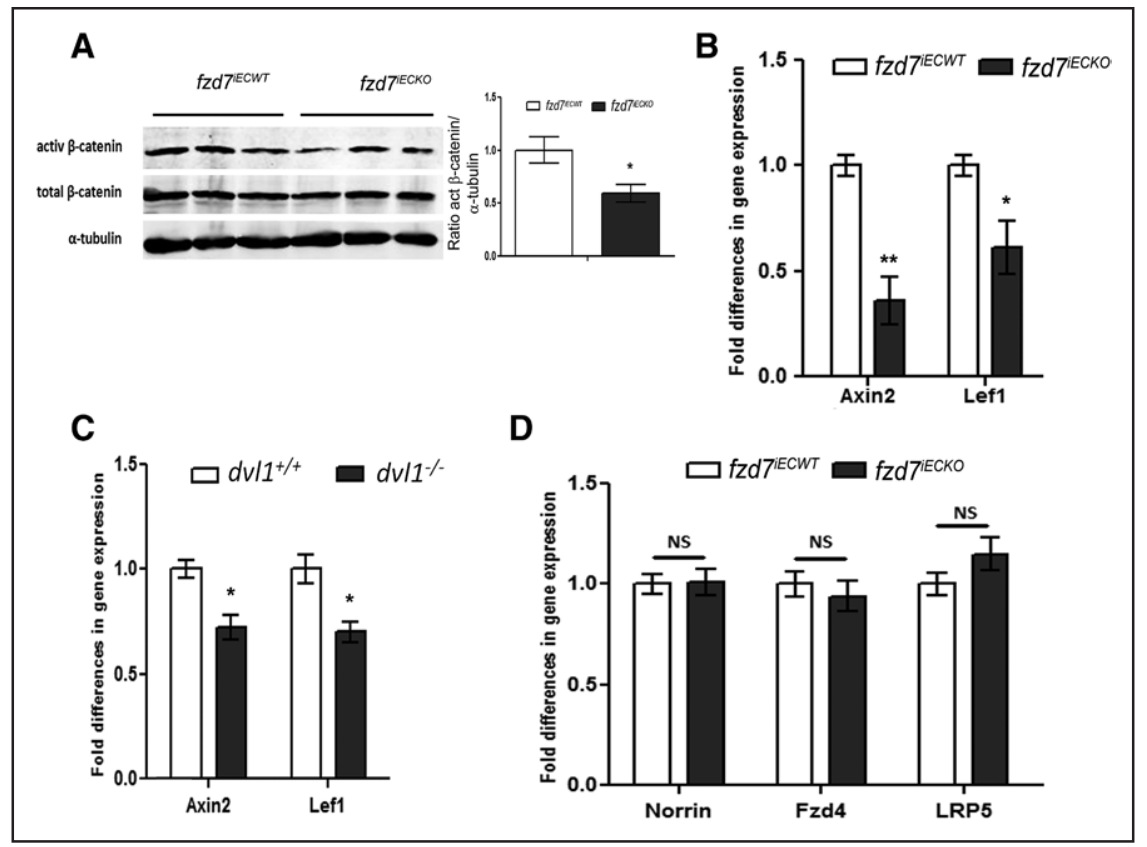

Figure 5. $f z d 7$ (frizzled-7) and $D v / 1$ (dishevelled-1) deletion decrease Wnt/ $\beta$ catenin signaling in the retina. A, Western blot of total lysate from $f z d 7^{E E C W T}$ and $f z d 7^{i E C K O}$ retina, active $\beta$-catenin, total $\beta$-catenin, and $\alpha$-tubulin staining were performed (3 different mice). The ratio of active $\beta$-catenin/total $\beta$-catenin showed a decrease in $\beta$-catenin activation in $f z d 7^{E} E C K O$ vs $f z d 7^{i E W T}$. B and C, qRT-PCR analysis of the Wnt-canonical signaling target genes Axin2 and lef1 was performed in whole retina from P5 $f z d 7^{i E C W T}$ and $f z d 7^{i E C K O}$ mice (B) and from $d v / 1^{-/-} v s d v / 1^{+/+}$mice (C). A decrease in Wnt-canonical target gene expression was observed in $\mathrm{fzd} 7$ mutant and $d v / 1^{-1-}$ mice. D, qRT-PCR of $f z d 4$, $L R P 5$, and Norrin was performed in whole retina from $P 5 f z d 7^{i E C W T}$ and $f z d 7^{i E C K O}$ mice. No difference in gene expression was observed. ${ }^{\star} P<0.05$. 


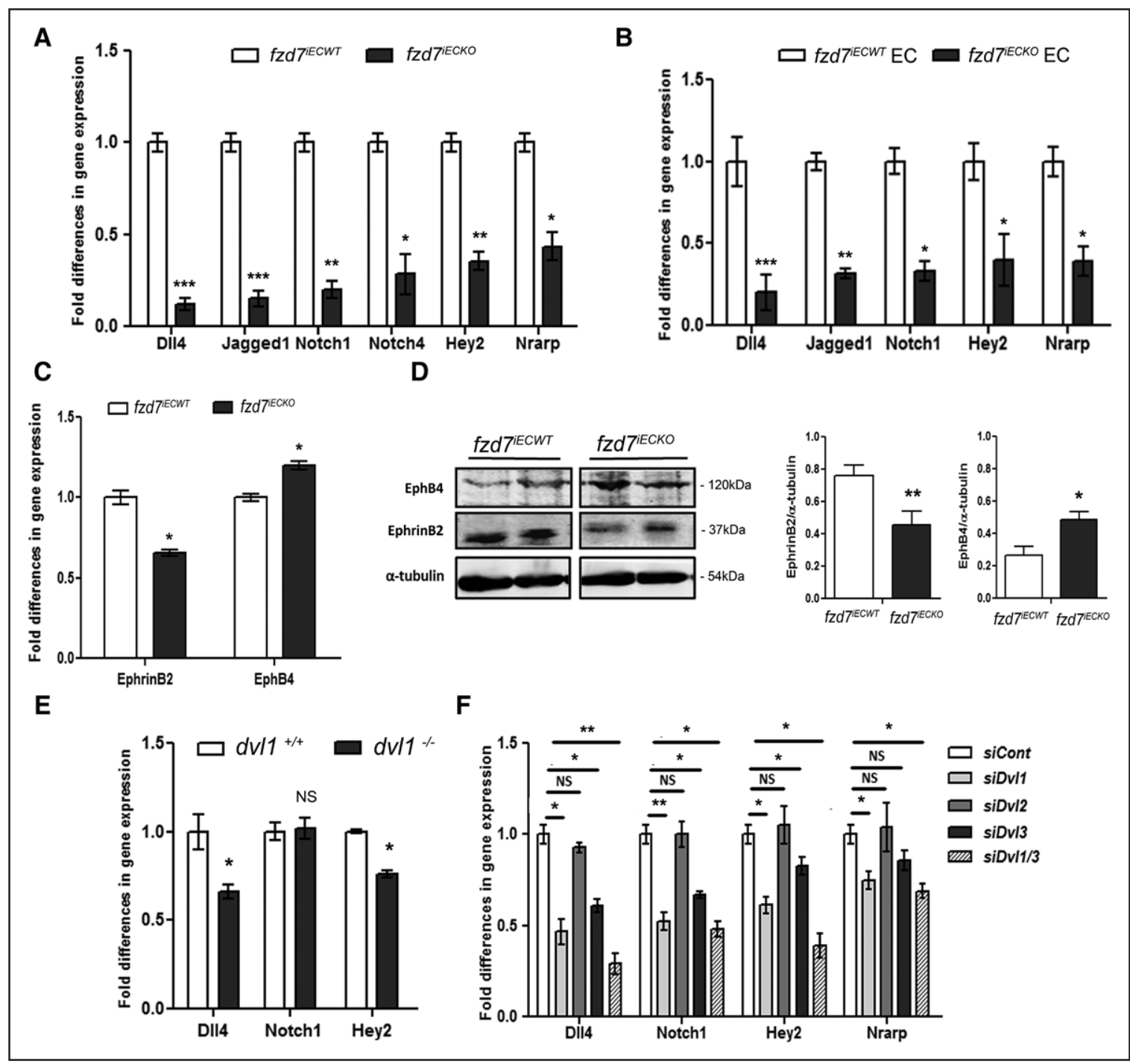

Figure 6. Fzd7 (frizzled-7)/Dvl1/3 (dishevelled-1/3) regulates Notch signaling. A, qRT-PCR of DIl4/Notch signaling target genes in whole

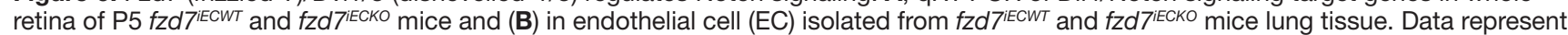
the mean of 3 to 6 experiments performed in triplicate. C, qRT-PCR of EphrinB2 and EphB4 expression in the whole retina from postnatal day $(P) 5 f z d 7^{i E C W T}$ and $f z d 7^{i E C K O}$ mice. The expression level of all genes was normalized against the housekeeping gene $\beta$-actin. Data represent the mean of 4 experiments performed in triplicate. D, A representative Western blot analysis of EphB4, EphrinB2, and $\alpha$-tubulin expression of retina lysates from 2 different $f z d 7^{i E C W T}$ and $f z d 7^{i E C K O}$ mice. Graph represents quantification of 3 independent experiments. E, qRT-PCR of DII4/Notch signaling target genes in whole retina of P5 $d v / 1^{+/+}$and $d v / 1^{-/-}$mice and (F) in MS1 treated with siCont, sidv/1, sidv/2, and sidv/3 or cotreated with sidv/1 and sidv/3 (sidv/1/3). The expression level of all genes was normalized against the housekeeping gene $\beta$-actin. Data represent the mean of 4 experiments performed in triplicate. ${ }^{*} P<0.05 ;{ }^{* \star} P<0.005 ;{ }^{* *} P<0.0001$.

Fzd signaling to relay cellular information. Genetic studies have reported that the different orthologs have unique but also overlapping functions. However, evidence for their functional specialization in distinct organs and cellular events remain largely unexplored. ${ }^{38,39}$ Previously, we demonstrated that Dvl1 and 3 can be recruited at the cell membrane by Fzd7 in EC to activate cell signaling. ${ }^{25}$ Our results indicate that mice deficient in $d v l l$ display a similar but relatively milder retinal vascular phenotype, compared with the phenotype observed in mice deficient in EC-specific $f z d 7$. Moreover, a worsening of the vascular phenotype was observed after injection of $d v l 3$ siRNA in $d v l 1^{-/-}$mice. Using this strategy to target expression of $d v l l / 3$ in the retina, we circumvented early embryonic lethality of $d v l 1^{--/} / d v l 3^{---}$double mutants ${ }^{39}$ and have been able to identify Dvl1/Dvl3 pathway dependence for angiogenic events in vivo.
In the present study, a decrease of Wnt-canonical activation and target genes expression, specifically Axin 2 and lefl, was observed in $f z d 7$ iECKO retinas and $d v l 1^{-/-}$retinas. Our data are in line with results from our recent study demonstrating that Fzd7 actives the Wnt canonical pathway in EC. ${ }^{13} \mathrm{We}$ then demonstrated that retinal vascular defects in $f z d 7^{i E C K O}$ were rescued by treatment with $\mathrm{LiCl}$. Although we cannot rule out non-EC effects of $\mathrm{LiCl}$ in vivo, these experiments strongly support the notion that Fzd7 expressed by EC controls vascular retinal development through Wnt canonical signaling. These results are in accordance with the literature reporting a major role of $\mathrm{Wnt} / \beta$-catenin for retinal vessel development ${ }^{11,27,36}$ and blood-retinal barrier integrity. ${ }^{40}$

Previous work has demonstrated that during angiogenesis, the proper balance of tips/stalk cells is highly dynamic and is 


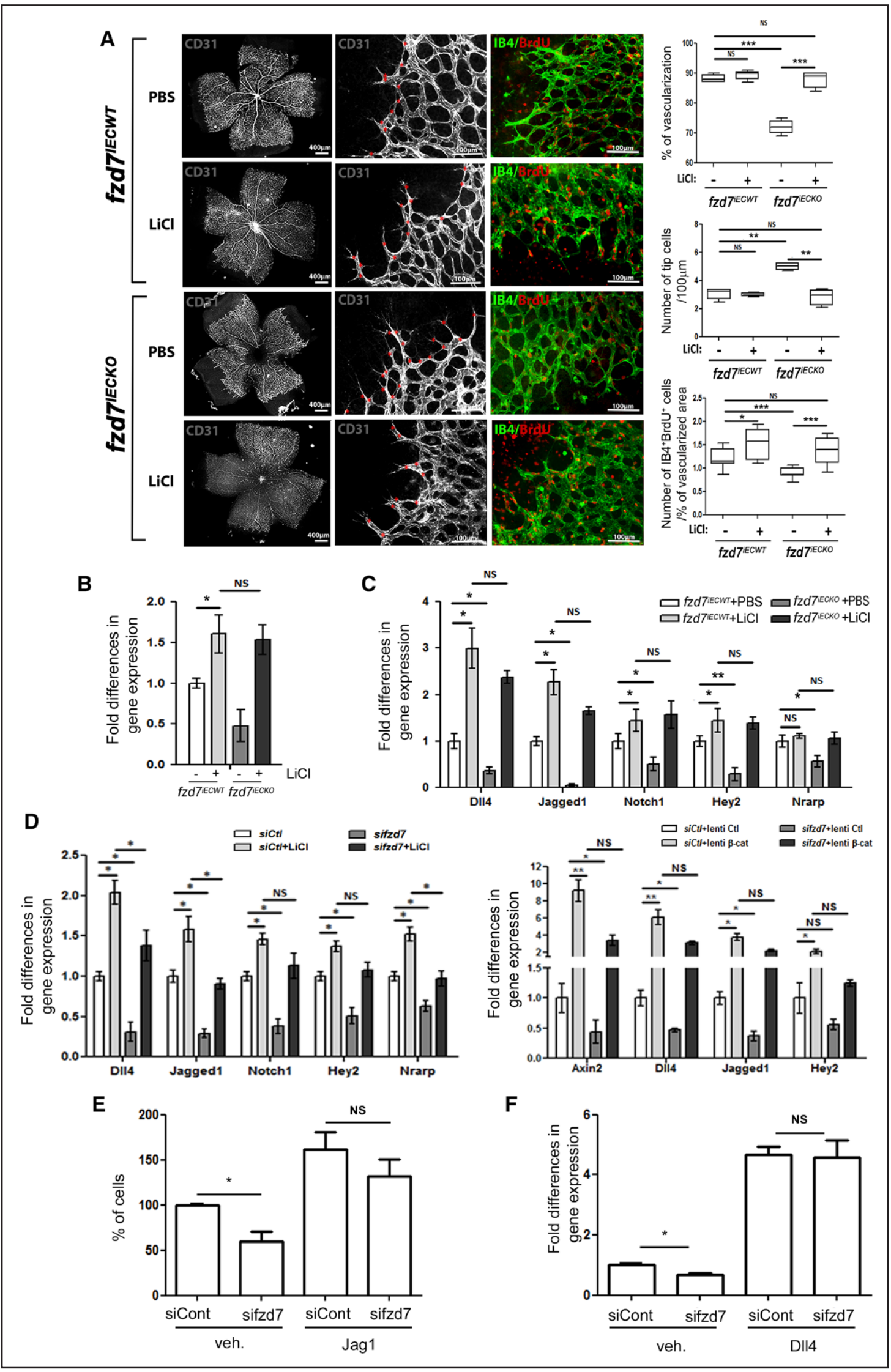

Figure 7. Fzd7 (frizzled-7) controls postnatal angiogenesis and Notch signaling via the canonical Wnt/ $\beta$-catenin pathway. A, Representative retinal whole mounts and peripheral retinal flat mounts $48 \mathrm{~h}$ after injection of LiCl or PBS from postnatal day $(\mathrm{P}) 7 \mathrm{fzd} 7_{\mathrm{iECWT}}$ and $f z d 7^{\mathrm{E} E C K O}$ mice. LiCl treatment rescues vascular delay and tip cell number impairment. Isolectin B4 (IB4)/BrdU (bromo-desoxy-uridin; (Continued) 
Figure 7 Continued. right) staining showed that $\mathrm{LiCl}$ rescues endothelial cell (EC) proliferation impaired in fzd7 mutant mice. Quantification of \% vascularization, number of tip cells per $100 \mu \mathrm{m}$, and proliferation of EC: $\mathrm{n}=5$ mice for each condition. B, qRT-PCR was performed in whole retina from P7 fzd7iECWT and fzd7iECKO mice treated with LiCl or PBS. LiCl injection increased lef1 expression in both control and mutant mice. The expression level of all genes was normalized against the housekeeping gene $\beta$-actin. C, qRT-PCR was performed in retina from P7 fzd $7^{E E C W T}$ and $f z d 7^{E C K O}$ mice treated with $\mathrm{LiCl}$ or PBS. LiCl treatment rescues Notch gene expression in $f z d 7$ mutant mice. D, qRT-PCR was performed in siRNA control (siCont) or siRNA fzd7 (sifzd7) treated MS1 after $24 \mathrm{~h}$ of LiCl activation or control medium. Knockdown of $f z d 7$ in EC decreases Notch gene expression. LiCl treatment rescues decreased expression induced by sifzd7 treatment. Data represent the mean of 3 to 6 experiments performed in triplicate. MS1 cells were transfected with siCont or sifzd7 and transduced with lentivirus encoding for active $\beta$-catenin. qRT-PCR showed that activated $\beta$-catenin rescues Notch expression impairment induced by silencing of $f z d 7$. Expression level of all genes was normalized against the housekeeping gene $\beta$-actin. Data represent the mean of 3 to 4 experiments performed in triplicate. E. HUVEC (human umbilical vein endothelial cell) were treated with siCont or sifzd7 for $48 \mathrm{~h}$ then plated either on vehicle or Jag1-coated dishes. After $24 \mathrm{~h}$, EC count was quantified in each conditions ( $\mathrm{n}=13)$. Unpaired $t$ test on the average values obtained in 3 independent experiments. F, siCont- or sifzd7-treated HUVEC were plated on duplicate either on vehicle or DII4-coated dishes. qRT-PCR was performed after $24 \mathrm{~h}$ activation. The expression level of EphrinB2 was normalized against the housekeeping gene $\beta$-actin $(\mathrm{n}=3)$. ${ }^{\star} P<0.01$; ${ }^{* *} P<0.05 ;{ }^{* \star *} P<0.001$.

mediated by a balanced expression and interaction of the Notch1 receptor with its ligands Dll4 and Jag1. ${ }^{1}$ Dll4 in tip cells activates Notch in adjacent stalk cells to laterally inhibit tip cell selection and maintain the hierarchical organization of sprouting EC. In contrast, Jag1 in stalk cells impedes Notch signaling in adjacent tip cell..$^{32,41,42}$ Interestingly, although the control of Notch ligand by $\beta$-catenin is still not clear in postnatal retinal vascularization, ${ }^{10}$ cross talk between $\beta$-catenin and Notch signaling has been reported in different conditions. Dll4 was shown to be a direct transcriptional target of $\mathrm{Wnt} / \beta$-catenin in EC. ${ }^{10,12} \beta$-Catenin may form a complex with NICD/RBP-J on the Dll4 promoter, thereby potentiating the Dll4/Notch signal, leading to vascular stabilization. ${ }^{43}$ Other studies report that $\beta$-catenin actives Jag1 transcription leading to Notch activation in epithelial cells of the skin and cancer cells. ${ }^{30,44,45}$ Moreover, Phng et al ${ }^{11}$ link the canonical Wnt pathway downstream of Notch signaling because the transcriptional factor Nrarp expressed in stalk cells at branch points limits Notch signaling and conversely stimulates Lef1 to regulate stalk cell proliferation. This underscores the importance of studies that investigate a role of upstream signaling that regulates Notch signaling. In this context, we propose that Fzd7 signaling, in controlling both Dll4 and Jagged1 Notch ligand expression through $\beta$-catenin activation, participates in retinal vascular plexus formation. First, our data show that Fzd7 controls Dll4 expression in tip cells. These results indicate that Fzd7 may participate to the lateral inhibition required for tip/stalk cell specification. In addition, it was reported that the strong proliferation of stalk cells contributes to sustained growth of the primary retinal vascular plexus ${ }^{22}$ and that $\beta$-catenin signalization is active in stalk cells. ${ }^{11,46}$ Interestingly, $f z d 7$ mutants displayed reduced stalk cell proliferation and decreased lef1 expression involved in cell proliferation. ${ }^{47}$ In concordance, we report that depletion of $f z d 7$ delays plexus development correlated with a decrease of stalk cell proliferation and a decrease of Jagged1 expression. Mechanistically, we propose that Fzd7 controls EC proliferation via the regulation of the $\mathrm{Wnt} / \beta$-catenin signaling regulators, lef1 and partially via Jag1. Finally, Dll4-dependent Notch signaling controls the arterial marker EphrinB2 expression. ${ }^{31}$ Our work demonstrates that depletion of $f z d 7$ decreases EphrinB2 expression in the retinal vascular plexus and in cultured EC. Rescue experiments with Dll4 ligand suggest that Fzd7 signaling could control EphrinB2 expression via Dll4 (Figure V in the onlineonly Data Supplement).

In summary, we identified Fzd7 as a relevant Fzd receptor that contributes to retinal vascular plexus development and provides novel molecular insight into the reciprocal interaction of the Wnt/Fzd canonical and Notch pathways in regulating vessel formation.

\section{Sources of Funding}

This work was supported by grants from the Agence Nationale de la Recherche (ANR-2010-Blanc-1135-01), from Region Aquitaine (20101301039MP), and from Fondation pour la Recherche Médicale FRM (FRM Vision DVS20131228623). C. Peghaire was a recipient of a fellowship from French Ministry and from GRRC. R. Sewduth was a recipient of a fellowship from Aquitaine Region and Inserm.

\section{Disclosures}

None.

\section{References}

1. Eilken HM, Adams RH. Dynamics of endothelial cell behavior in sprouting angiogenesis. Curr Opin Cell Biol. 2010;22:617-625. doi: 10.1016/j. ceb.2010.08.010.

2. Franco CA, Liebner S, Gerhardt H. Vascular morphogenesis: a Wnt for every vessel? Curr Opin Genet Dev. 2009;19:476-483. doi: 10.1016/j. gde.2009.09.004

3. Dejana E. The role of wnt signaling in physiological and pathological angiogenesis. Circ Res. 2010;107:943-952. doi: 10.1161/CIRCRESAHA. 110.223750 .

4. Reis M, Liebner S. Wnt signaling in the vasculature. Exp Cell Res. 2013;319:1317-1323. doi: 10.1016/j.yexcr.2012.12.023.

5. Wodarz A, Nusse R. Mechanisms of Wnt signaling in development. Annu Rev Cell Dev Biol. 1998;14:59-88. doi: 10.1146/annurev.cellbio.14.1.59.

6. van Amerongen R, Nusse R. Towards an integrated view of Wnt signaling in development. Development. 2009;136:3205-3214. doi: 10.1242/dev.033910.

7. Logan CY, Nusse R. The Wnt signaling pathway in development and disease. Annu Rev Cell Dev Biol. 2004;20:781-810. doi: 10.1146/annurev. cellbio.20.010403.113126.

8. MacDonald BT, Tamai K, He X. Wnt/beta-catenin signaling: components, mechanisms, and diseases. Dev Cell. 2009;17:9-26. doi: 10.1016/j. devcel.2009.06.016.

9. Roca C, Adams RH. Regulation of vascular morphogenesis by Notch signaling. Genes Dev. 2007;21:2511-2524. doi: 10.1101/gad.1589207.

10. Corada M, Nyqvist D, Orsenigo F, Caprini A, Giampietro C, Taketo MM, Iruela-Arispe ML, Adams RH, Dejana E. The Wnt/beta-catenin pathway modulates vascular remodeling and specification by upregulating Dll4/Notch signaling. Dev Cell. 2010;18:938-949. doi: 10.1016/j.devcel.2010.05.006.

11. Phng LK, Potente M, Leslie JD, Babbage J, Nyqvist D, Lobov I, Ondr JK, Rao S, Lang RA, Thurston G, Gerhardt H. Nrarp coordinates endothelial Notch and Wnt signaling to control vessel density in angiogenesis. Dev Cell. 2009;16:70-82. doi: 10.1016/j.devcel.2008.12.009.

12. Reis M, Czupalla CJ, Ziegler N, Devraj K, Zinke J, Seidel S, Heck R, Thom S, Macas J, Bockamp E, Fruttiger M, Taketo MM, Dimmeler S, Plate KH, Liebner $\mathrm{S}$. Endothelial Wnt/ $\beta$-catenin signaling inhibits glioma angiogenesis and normalizes tumor blood vessels by inducing PDGF-B expression. J Exp Med. 2012;209:1611-1627. doi: 10.1084/jem.20111580.

13. Ferreira Tojais N, Peghaire C, Franzl N, Larrieu-Lahargue F, Jaspard B, Reynaud A, Moreau C, Couffinhal T, Duplàa C, Dufourcq P. Frizzled7 controls vascular permeability through the Wnt-canonical pathway and 
cross-talk with endothelial cell junction complexes. Cardiovasc Res. 2014;103:291-303. doi: 10.1093/cvr/cvu133.

14. Abu-Elmagd M, Garcia-Morales C, Wheeler GN. Frizzled7 mediates canonical Wnt signaling in neural crest induction. Dev Biol. 2006;298:285298. doi: 10.1016/j.ydbio.2006.06.037.

15. Winklbauer R, Medina A, Swain RK, Steinbeisser H. Frizzled-7 signalling controls tissue separation during Xenopus gastrulation. Nature. 2001;413:856-860. doi: 10.1038/35101621.

16. Flanagan DJ, Phesse TJ, Barker N, et al. Frizzled7 functions as a Wnt receptor in intestinal epithelial Lgr5(+) stem cells. Stem Cell Reports. 2015;4:759-767. doi: 10.1016/j.stemcr.2015.03.003.

17. Fernandez A, Huggins IJ, Perna L, Brafman D, Lu D, Yao S, Gaasterland T, Carson DA, Willert K. The WNT receptor FZD7 is required for maintenance of the pluripotent state in human embryonic stem cells. Proc Natl Acad Sci USA. 2014;111:1409-1414. doi: 10.1073/pnas.1323697111.

18. Melchior K, Weiss J, Zaehres H, Kim YM, Lutzko C, Roosta N, Hescheler J, Müschen M. The WNT receptor FZD7 contributes to self-renewal signaling of human embryonic stem cells. Biol Chem. 2008;389:897-903. doi: 10.1515/BC.2008.108.

19. King TD, Zhang W, Suto MJ, Li Y. Frizzled7 as an emerging target for cancer therapy. Cell Signal. 2012;24:846-851. doi: 10.1016/j.cellsig.2011.12.009.

20. Phesse T, Flanagan D, Vincan E. Frizzled7: a promising Achilles' Heel for targeting the Wnt receptor complex to treat cancer. Cancers (Basel). 2016;8. doi: 10.3390/cancers8050050.

21. Stefater JA 3rd, Lewkowich I, Rao S, et al. Regulation of angiogenesis by a non-canonical Wnt-Flt1 pathway in myeloid cells. Nature. 2011;474:511515. doi: 10.1038/nature10085.

22. Gerhardt H, Golding M, Fruttiger M, Ruhrberg C, Lundkvist A, Abramsson A, Jeltsch M, Mitchell C, Alitalo K, Shima D, Betsholtz C. VEGF guides angiogenic sprouting utilizing endothelial tip cell filopodia. J Cell Biol. 2003;161:1163-1177. doi: 10.1083/jcb.200302047.

23. Phng LK, Stanchi F, Gerhardt H. Filopodia are dispensable for endothelial tip cell guidance. Development. 2013;140:4031-4040. doi: 10.1242/dev.097352.

24. Ehling M, Adams S, Benedito R, Adams RH. Notch controls retinal blood vessel maturation and quiescence. Development. 2013;140:3051-3061. doi: 10.1242/dev.093351.

25. Descamps B, Sewduth R, Ferreira Tojais N, Jaspard B, Reynaud A, Sohet F, Lacolley P, Allières C, Lamazière JM, Moreau C, Dufourcq P, Couffinhal T, Duplàa C. Frizzled 4 regulates arterial network organization through noncanonical Wnt/planar cell polarity signaling. Circ Res. 2012;110:47-58. doi: 10.1161/CIRCRESAHA.111.250936.

26. Xu Q, Wang Y, Dabdoub A, Smallwood PM, Williams J, Woods C, Kelley MW, Jiang L, Tasman W, Zhang K, Nathans J. Vascular development in the retina and inner ear: control by Norrin and Frizzled-4, a high-affinity ligand-receptor pair. Cell. 2004;116:883-895.

27. Junge HJ, Yang S, Burton JB, Paes K, Shu X, French DM, Costa M, Rice DS, Ye W. TSPAN12 regulates retinal vascular development by promoting Norrin- but not Wnt-induced FZD4/beta-catenin signaling. Cell. 2009;139:299-311. doi: 10.1016/j.cell.2009.07.048.

28. Xia CH, Liu H, Cheung D, Wang M, Cheng C, Du X, Chang B, Beutler B, Gong X. A model for familial exudative vitreoretinopathy caused by LPR5 mutations. Hum Mol Genet. 2008;17:1605-1612. doi: 10.1093/ $\mathrm{hmg} / \mathrm{ddn} 047$.

29. Ye X, Wang Y, Cahill H, Yu M, Badea TC, Smallwood PM, Peachey NS, Nathans J. Norrin, frizzled-4, and Lrp5 signaling in endothelial cells controls a genetic program for retinal vascularization. Cell. 2009;139:285298. doi: 10.1016/j.cell.2009.07.047.

30. Estrach S, Ambler CA, Lo Celso C, Hozumi K, Watt FM. Jagged 1 is a beta-catenin target gene required for ectopic hair follicle formation in adult epidermis. Development. 2006;133:4427-4438. doi: 10.1242/dev.02644.
31. Iso T, Maeno T, Oike Y, Yamazaki M, Doi H, Arai M, Kurabayashi M. Dll4-selective Notch signaling induces ephrinB2 gene expression in endothelial cells. Biochem Biophys Res Commun. 2006;341:708-714. doi: 10.1016/j.bbrc.2006.01.020.

32. Benedito R, Roca C, Sörensen I, Adams S, Gossler A, Fruttiger M, Adams RH. The notch ligands D114 and Jagged1 have opposing effects on angiogenesis. Cell. 2009;137:1124-1135. doi: 10.1016/j.cell.2009.03.025.

33. Ishikawa T, Tamai Y, Zorn AM, Yoshida H, Seldin MF, Nishikawa S, Taketo MM. Mouse Wnt receptor gene Fzd5 is essential for yolk sac and placental angiogenesis. Development. 2001;128:25-33.

34. Liu C, Nathans J. An essential role for frizzled 5 in mammalian ocular development. Development. 2008;135:3567-3576. doi: 10.1242/dev.028076.

35. Daneman R, Agalliu D, Zhou L, Kuhnert F, Kuo CJ, Barres BA. Wnt/betacatenin signaling is required for CNS, but not non-CNS, angiogenesis. Proc Natl Acad Sci USA. 2009;106:641-646. doi: 10.1073/pnas.0805165106.

36. Ye X, Wang Y, Nathans J. The Norrin/Frizzled4 signaling pathway in retinal vascular development and disease. Trends Mol Med. 2010;16:417425. doi: 10.1016/j.molmed.2010.07.003.

37. Wang Y, Rattner A, Zhou Y, Williams J, Smallwood PM, Nathans J. Norrin/ Frizzled 4 signaling in retinal vascular development and blood brain barrier plasticity. Cell. 2012;151:1332-1344. doi: 10.1016/j.cell.2012.10.042.

38. Wynshaw-Boris A. Dishevelled: in vivo roles of a multifunctional gene family during development. Curr Top Dev Biol. 2012;101:213-235. doi: 10.1016/B978-0-12-394592-1.00007-7.

39. Etheridge SL, Ray S, Li S, Hamblet NS, Lijam N, Tsang M, Greer J, Kardos N, Wang J, Sussman DJ, Chen P, Wynshaw-Boris A. Murine dishevelled 3 functions in redundant pathways with dishevelled 1 and 2 in normal cardiac outflow tract, cochlea, and neural tube development. PLoS Genet. 2008;4:e1000259. doi: 10.1371/journal.pgen.1000259.

40. Zhou Y, Wang Y, Tischfield M, Williams J, Smallwood PM, Rattner A, Taketo MM, Nathans J. Canonical WNT signaling components in vascular development and barrier formation. J Clin Invest. 2014;124:3825-3846. doi: $10.1172 / J C I 76431$.

41. Hellström M, Phng LK, Hofmann JJ, et al. Dll4 signalling through Notch1 regulates formation of tip cells during angiogenesis. Nature. 2007;445:776-780. doi: 10.1038/nature05571.

42. Lobov IB, Renard RA, Papadopoulos N, Gale NW, Thurston G, Yancopoulos GD, Wiegand SJ. Delta-like ligand 4 (Dl14) is induced by VEGF as a negative regulator of angiogenic sprouting. Proc Natl Acad Sci USA. 2007;104:3219-3224. doi: 10.1073/pnas.0611206104.

43. Zhang J, Fukuhara S, Sako K, Takenouchi T, Kitani H, Kume T, Koh GY, Mochizuki N. Angiopoietin-1/Tie2 signal augments basal Notch signal controlling vascular quiescence by inducing delta-like 4 expression through AKT-mediated activation of beta-catenin. J Biol Chem. 2011;286:8055-8066. doi: 10.1074/jbc.M110.192641.

44. Rodilla V, Villanueva A, Obrador-Hevia A, et al. Jagged1 is the pathological link between Wnt and Notch pathways in colorectal cancer. Proc Natl Acad Sci USA. 2009;106:6315-6320. doi: 10.1073/pnas.0813221106.

45. Chen X, Stoeck A, Lee SJ, Shih IeM, Wang MM, Wang TL. Jagged1 expression regulated by Notch3 and Wnt//-catenin signaling pathways in ovarian cancer. Oncotarget. 2010;1:210-218. doi: 10.18632/oncotarget.127.

46. Franco CA, Jones ML, Bernabeu MO, Vion AC, Barbacena P, Fan J, Mathivet T, Fonseca CG, Ragab A, Yamaguchi TP, Coveney PV, Lang RA, Gerhardt H. Non-canonical Wnt signalling modulates the endothelial shear stress flow sensor in vascular remodelling. Elife. 2016;5:e07727. doi: 10.7554/eLife.07727.

47. Masckauchán TN, Shawber CJ, Funahashi Y, Li CM, Kitajewski J. Wnt/ beta-catenin signaling induces proliferation, survival and interleukin-8 in human endothelial cells. Angiogenesis. 2005;8:43-51. doi: 10.1007/ s10456-005-5612-9.

\section{Highlights}

- Specific Fzd7 (frizzled-7) deletion in endothelial cells inhibits postnatal angiogenesis by controlling tip cell phenotype and stalk cell proliferation.

- Dvl3 downregulation expression in Dvl1-deficient mice phenocopies Fzd7 phenotype.

- Fzd7 acts via the Wnt canonical pathway to control vessel formation.

- $\mathrm{Fzd} / / \beta$-catenin acts upstream of Notch signaling. 